to be continued over a long period, and which requires the co-operation of many independent workers in university departments and laboratories, can probably be organized more easily by the Royal Society than by a Government department, however much the latter may be in sympathy with the object of the researches. The Royal Society has already shown its willingness to further such work by appointing Dr. E. Glückauf to a Mackinnon Studentship, to enable him to carry out meteorological research under the general guidance of the Gassiot Committee.

The general research in which the Air Ministry has sought the co-operation of the Royal Society is that of radiation in the atmosphere, with special reference to radiation equilibrium conditions in the stratosphere. It is fairly generally accepted that the average temperature of the stratosphere-as of the warm region above it-is determined by an equilibrium between the energy absorbed, from both the downward solar radiation and the upward terrestrial radiation, and the energy radiated by the air in the stratosphere. Observations have shown that there are large variations of temperature in the stratosphere both with time and with place, but we know little as to why such variations occur. Few meteorologists, for example, would care to be dogmatic as to why the stratosphere is some $59^{\circ} \mathrm{C}$. colder in equatorial regions than in polar regions.

The principal gases of the atmosphere are mostly very transparent to radiation, and the radiative conditions are largely governed by such minor but polyatomic constituents as water vapour, carbon dioxide, ozone and possibly others. To understand the radiation equilibrium in the atmosphere, it is necessary to know $(a)$ what gases are present which have important absorption bands for radiation; (b) in what proportions they are present at different levels; (c) how gases such as ozone are formed and decomposed ; (d) the absorption coefificients of these gases for different wave-lengths, and whether the absorption and emission spectra have a continuous or fine line structure. Finally, when the above facts are determined, it will be necessary to calculate the radiation equilibrium temperatures at different levels and to determine how rapidly the temperature will change when the conditions alter.

The Gassiot Committee has been fortunate in enlisting expert help in particular branches of the subjects involved, and has formed three sub-committees to deal with different aspects of the above question. It is hoped in this way that the available relevant knowledge will be collected, and that those questions which require more experimental work may be defined, so that arrangements can be made for the work to be done, so far as this should prove possible under present conditions.

Dr. G. M. B. Dobson is the chairman of SubCommittee A, which will deal with the chemical analysis and the observation of the amounts of the polyatomic constituents of the air at different levels ; other members of this sub-committee are Profs. H. Dingle and F. A. Paneth, and Dr. E. Glückauf.

Sub-Committee B will deal with the photophysics and photochemistry of the atmosphere, from the highest levels downwards, and, in particular, with the changing equilibrium of ozone and any other variable polyatomic constituents; the chairman of this sub-committee is Prof. H. W. Massey, and the members are Prof. K. G. Emeléus, Dr. W. C. Price, and Dr. J. Sayers.

Sub-committee $\mathbf{C}$ will consider the radiation balance in the atmosphere ; its chairman is Prof. S. Chapman, and its members are Prof. D. Brunt, Dr. G. S. Callendar, Dr. T. G. Cowling, Dr. A. R. Meetham, Sir George Simpson, and Dr. G. B. B. M. Sutherland.

There will be few who will not agree that the first meteorological problem thus selected for attack is a very important one, and still fewer who will dispute its difficulty. It is hoped that the scientific effort which the Royal Society can bring to bear on this work will lead to substantial progress. The Gassiot Committee is aware that at laboratories and institutions in many parts of the world work has been undertaken that bears on these problems, and the Committee would welcome co-operation in cases where the continuance of such work is possible in present circumstances.

\section{SCIENCE AND TECHNOLOGY IN THE SOVIET UNION}

CCIENCE and technology in the Soviet Union was $\checkmark$ the subject of the first of the two symposia held over the Easter wesk-end by the Faculty of Science of Marx House (Marx Memorial Library and Workers' School) at the London School of Hygiene and Tropical Medicine. Prof. J. B. S. Haldane presided and nine speakers took part in the two sessions. The second session, on Race and Fascism, was dealt with in NATURE of April 18, p. 426.

Prof. J. D. Bernal spoke on physical science in the U.S.S.R. A great deal of fundamontal work has been done in the Soviet Union and many dificulties have been overcome. In 1920 there wəre only forty trained physicists in the whole country, but by 1934 in the big institutes in Leningrad there was a six years course which was more rigorous than that in the Cavendish Laboratory. Since then tens of thousands of physicists had bəon trained. Physics played a vital part in the general plan of development and in the preparations for the expocted attack on the country.

As an example of the manner in which the fundamental problems studied arose from the neads of Soviet economy, Prof. Bernal took the transmission of electric power. Power losses which were trivial in Britain became sorious because of the great distances in the Soviet Union. The properties of insulators had to be studied and this required fundamental work on the passage of electricity through crystals and on the quantum theory of the solid state. In the metal industry, also, problems arose which led to a rapid development of crystal physics under Joffe and to the working out of a dynamic theory of plastic deformation. Rehbinder's discovery that the hardness of metals varies according to the surrounding medium is a fundamental one and has already led to changes of technique in dealing with metals.

Science is planned in the U.S.S.R. as a part of economy as a whole on the basis that, statistically, the results will be proportional to the effort applied in any particular field. Only the general requirements are given from outside, and the Academy of Sciences works out in general where the main lines of attack should be made. Each group of workers in each laboratory settles its own problems of how to go about the work. To-day the whole of Soviet science has been turned to the job of winning the War, to the problems of the production and use of 
new weapons, to the reorganization of industry in new areas, and to the discovery of new materials and sources of supply. The present lack of contact between Soviet men of science and those of other countries is very much to be deplored, and knowledge of what they are doing would help us to realize in a rational way the possibilities of science for a new civilization.

Mr. H. P. Vowles, speaking on electrification in the Soviet Union, said that Lenin, with his genius for applying Marxist theory to a concrete situation, realized very early that the new Soviet State would be menaced from within as well as from outside so long as small-scale methods remained the dominant mode of production. He realized that it would be impossible to build up large-scale production without electrification, hence his well-known saying that in Russia "Socialism was the Soviet Power plus Electrification". On Lenin's initiative the Conmission on Electrification known as GOELRO began work and soon achieved the first success of the new State in industrialization.

Mr. Vowles stated that, although the United States still leads the world in output per capita of electricity, the Soviet Union has drawn level with that country in many features of electrification and has surpassed it in rate of electric development, in the development of heat and power stations, in the mechanization and electrification of agriculture and in the correlated planning of production and consumption of electricity. The United States originally took its engineering technique from Britain, but from 1850 Britain drew increasingly on American technology and skill. The Soviet Union has been greatly indebted to the United States for the technique of power production, but already after the short period of twenty years the Americans can learn much from Soviet electrification.

Dr. N. F. M. Henry discussed the part of geology in Soviet ecónomy. He showed that although there were a few geologists of international standing in Tsarist Russia, less than 1 per cent of the vast area of the empire had been mapped on a scale of 1 -inch to one mile. From the beginning, the Soviet Government paid special attention to geology because the fundamental position of this science in the building of a socialist economy was realized. The electrification and industrialization of the country urgently demanded coal, iron and large supplies of many other mineral substances. Because of the great distances involved it was of vital importance to develop mineral supplies in many parts of the country. It was impossible to survey the 8 million square miles of the Soviet Union square by square as was done in Britain over a period of a hundred years. Soviet geologists were faced with a double problem of teaching thousands of young geologists and of developing geochemical theory as a guide to the rapid study of the most suitable areas for mineral exploitation. The mineral output of the Soviet Union to-day is evidence that these big problems were tackled with energy and with very good organization. It is no accident that Soviet men of science should lead the world in geochemistry, for its development was urgently demanded by the needs of Soviet economy.

In 1936 the total amount spent on geological work was 1,000 million roubles (about $£ 38,000,000$ ), but in March 1938 it was officially stated that this was to be doubled. The permanent scientific staff of the Central Institute for Geology numbers 500, but the total number of geologists and prospectors working under its control is about 10,000. These figures show the importance of geology to the Soviet Union, and this importance is reflected in the tremendous public interest in the subject. Millions of school-children study it in the field and in the laboratories of the Pioneer Palaces. The man in the street often reads of the latest discoveries, and the leading geologists are public figures.

Mr. H. Rose spoke on aspects of Soviet developments in chemical engineering, dealing in particular with the underground gasification of coal and with the Soviet rubber industry. While proposals for the underground gasification of coal were first made many years ago by Mendeléeff, and by Sir William Ramsay who actually carried out trial bores in Great Britain, it was Lenin who first paid serious attention to the possibilities opened out by this revolution in technique. In 1937 experimental shafts were sunk, after much careful preparation, in the Donbas. The successful development on a wide scale which was begun in 1940 was made possible by the work of Kapitza, who recently received a Stalin Prize, on the low-pressure liquefaction of air, because a cheap supply of oxygen is required to improve the quality of the gas.

The social and economic implications of this new development are of tremendous importance, for one man can now do the work of ten miners. Mr. Rose believes that technical developments in steel blast furnaces will probably do away with the need for mining coal even for metallurgical coke, and then in the Soviet Union the hard and dangerous occupation of underground coal mining will disappear completely.

Although scientific men such as Kondakov and Lebedev, working under the old regime, made considerable contributions to the early study of rubber, it was not until after the Revolution that this study developed enormously and led to the production of synthetic rubber on a large scale from 1931 onwards. To-day the Soviet Union is probably the largest producer of synthetic rubber in the world, and 80 per cent of her requirements are now satisfied by the synthetic product. In addition, the rubber problem is being solved by the rapid development of the natural rubber-yielding plants Kok-Sagyz and Tau-Sagyz.

Dr. M. Ruhemann dealt with low-temperature research and development. He spoke in particular about the separation of natural and industrial gases, which necessitates the use of low temperatures and refrigerating machinery. The studies of Soviet scientific workers on the phase equilibria of different gaseous mixtures and of the solid-liquid mixtures of several binary and ternary systems are now well known. These findings were applied to coke-oven gas, and important results were soon obtained, such as the extraction of hydrogen of 97 per cent purity and the development of a new method of obtaining krypton. As a result of this scientific research, the Soviet Union now has a larger gas separation industry than any other country in the world, and this is of great importance for the heavy chemical industry.

The afternoon session was opened by Prof. J. B. S. Haldane, who spoke on the biological sciences in the U.S.S.R. In biochemistry, work has been done on the way in which a protein 'gets itself copied', and the emphasis has been on the study of processes rather than on the isolation of substances. In sheep genetics the Soviet Union is well ahead, and the beginnings of a chromosome map for sheep are now visible. New species of plants have been produced such as an octoploid wheat, and the great work of Vavilov on the systematics of cultivated plants has led to the 
development of types suitable for many parts of the vast territory.

Umanski's discovery that cancer tissue will act as an organizer is very important, and work is proceeding on the study of the conditions necessary for tissue to be capable of being organized. In medical techniques several advances have been made. The transfusion of cadaver blood is a regular procedure now, and it has been found that it is more effective than blood from living donors, although the reason for this is not yet known. The grafting of tissues from corpses was based on the idea that the distinction between life and death and between different organisms is not so fundamental as has been thought. By the use of such processes, Filatov and his assistants have probably restored sight to more people than all other surgeons in the world put together.

Soviet biology is linked not only with agriculture, but also with the development of fishing, hunting, the timber industry, and very closely with medicine. Nevertheless, it does much work of fundamental importance which is altering our theoretical approach to many biological problems.

Mr. J. L. Fyfe made a contribution on the genetics controversy in the U.S.S.R. In his opinion the clash between the geneticists and Lysenko, a physiologist, arose because of the close relation between science and technical needs. Vernalization is the opposite of plant-breeding in the sense that it is designed to produce improved forms of crops by treatment, not to select them by testing. The special importance of vernalization in the Soviet Union is 'its speed as compared with plant-breeding. In 1931 Stalin said that the Soviet Union was fifty or a hundred years behind the advanced countries, and he gave the country ten years to make up leeway. Prejudices have obscured the issues, and this controversy has developed in a period of strong anti-Soviet propaganda. Mr. Fyfe went on to discuss the relation between genetics and the ideas of Lysenko. These ideas are in many ways contradictory to the basic postulates of genetics, but it is significant that recent developments in genetics itself are doing very much the same thing. Genetics is thus approaching a crisis, and the work and ideas of Lysenko are contributing to this developing crisis. The crying need, however, is for careful experimental work to test the theories of Lysenko, for it would be as foolish to set him up as an infallible prophet as it is to dismiss his work lightly.

Mrs. Beatrice King spoke on science in Soviet school education, which, she said, can only be understood in its social and economic setting. In the struggle of an economically backward country to transform itself in a few years into an advanced one through the building of a socialist economy, science has been of prime importance. In education, also, the Soviet Union has passed through a period of intense struggle to become an advanced country and to develop among the people the scientific outlook which is essential for the building of socialism.

In school the approach is historical and international, and science is directly linked with social and economic problems so that children learn at an early stage to think scientifically and not to regard science as a separate subject. All children study scientific subjects experimentally as well as theoretically, but there is no specialization in ordinary schools. The text-books which are used in schools and in universities are generally the work of several writers and are always tried out for a year before being finally approved.

Outside school, science plays a large part in the lives of the children. Science and scientific discoveries bulk largely in the literature of children of all ages, while their plays and films often have scientific subjects. The children's Pioneer Palaces always have laboratories, and school science and exploration clubs flourish, while excursions to the country and to museums and regional-study holidays are attended by millions of children every year.

Dr. M. Ruhemann spoke on the scientific worker in Soviet society. Soviet men of science have closer contact with other strata of the population than is the case in Western countries, and they react to the pressure of public opinion from a people which has learned to respect science and to expect a lot from it. In most cases students receive a stipend from the State during their five-year course. The best students can proceed to do research work with increased stipends and are entitled to all the help that their seniors can give them. As a member of the same trade union as all other employees in the institution, whether technical, scientific or office workers, the man of science becomes bound up with the life of the institute. The intense Soviet life around, the unlimited scope for solving practical problems, and, finally, the basic Marxist conception of science as the foundation of technique and of the development of the productive forces of society make the scientific worker a conscious and enthusiastic citizen.

The whole symposium was attended by about 250 people, and Marx House is to be congratulated on the organization of such a successful set of meetings. These symposia constitute a valuable contribution to Anglo-Soviet unity and understanding.

\section{THE SCIENTIFIC WORK OF ELIE METCHNIKOFF}

\author{
By DR. G. F. PETRIE \\ Lister Institute
}

THE heightened interest in the cultural and intellectual activities of the U.S.S.R. has stimulated a desire to know more about the work of outstanding Russian men of science who belong to the recent past, and thus the anniversary of the birth of Metchnikoff on May 16, 1845, is a fitting time to survey his achievements and to indicate the significance at the present day of his fundamental work on the role of phagocytosis in inflammation and immunity.

Metchnikoff's training as a zoologist was of the greatest value to him throughout his life in guiding his researches, and indeed in consequence of it he was led to the central point of his theory of immunity, for during his stay at Messina in 1882 he made his observations on the mobile cells of a transparent starfish larva and conceived the idea that similar cells might serve to defend the organism against intruding particles whether these were living or non-living. A simple experiment carried out on the spot went far towards establishing the proof. As he himself wrote: "A zoologist until then, I suddenly became a pathologist." During the next twenty-five years the theory was extended by Metchnikoff and his pupils and by numerous workers in many parts of the world to 